\title{
Efficacy of different extracts of Allium chinense bulb against Sitotroga cerealella infestation in stored paddy grain, Oryza sativa
}

\author{
Thejanuo Rhetso' ${ }^{1}$ M.S. Roopa ${ }^{1}$, Abraham Verghese ${ }^{2}$, R. Shubharani ${ }^{1}$, \\ V. Sivaram ${ }^{1 *}$
}

${ }^{1}$ Department of Botany, Bangalore University, Bengaluru 560056, Karnataka, India

${ }^{2}$ ICAR-National Bureau of Agricultural Insect Resources, Bengaluru 560024, Karnataka, India

${ }^{\star}$ Corresponding author, E-mail: sivaram900@gmail.com

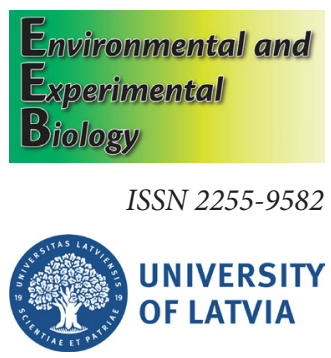

\begin{abstract}
Stored grain pest Sitotroga cerealella (Olivier) (Lepidoptera: Gelechiidae) is considered as one of the most destructive pests of cereal grains. The study aim was to develop methods to suppress moth emergence and reduce the weight loss of paddy grain (Oryza sativa L.) in storage using bulb extracts of Allium chinense G.Don from solvents of varying polarity (hexane, petroleum ether, chloroform, methanol, ethanol, and water). The results showed that all of the tested extracts had significant effect on the developmental period and moth emergence. The petroleum ether extract with $\mathrm{LC}_{50}$ value of $0.39 \%(0.16$ to $0.62 \%)$ and ethanol extract with $\mathrm{LC}_{50}$ of $0.45 \%(0.21$ to $0.68 \%$ ) exhibited remarkable activity against S. cerealella, as no moth emergence was observed when applied at $2 \%$ concentration. For the chloroform extract, $2 \%$ concentration showed the highest inhibition on the developmental stage, where moths emerged at 42.50 days, compared to 28.75 days in the control. The weight loss of paddy was best controlled with $2 \%$ ethanol extract (2.55\%); the highest loss was recorded in paddy treated with water extract. The present study concludes that petroleum ether and ethanol extract of bulbs of $A$. chinense have potential use in integrated pest management of S. cerealella for post-harvest protection of paddy, considering availability and easy propagation of the plant, and environmental friendliness.
\end{abstract}

Key words: Allium chinense, bulb extract, mortality, paddy (Oryza sativa), Sitotroga cerealella. Abbreviations: LCL, lower confidence limit; UCL, upper confidence limit.

\section{Introduction}

Food security has been defined as the ability of food deficit countries or regions within states to meet the target consumption level on a year-to-year basis (Valdes, Siamwalla 1981). Control of post-harvest loss would surge food availability, eliminate hunger and improve farmer's livelihoods. The management of pests in the field and storage is vital for food security. The stored grain pest, Sitotroga cerealella (Olivier), is also known as Angoumois grain moth and is considered one of the main storage grain pests in the Nagaland state of North-East India, where farmers usually use traditional storage structures (Jamir et al. 2013). Plant infestation by $S$. cerealella begins in the field before harvest, proceeds up to grain storage and increases with increasing moisture content (Bushra et al. 2013). The pest feeds on the superficial layers of the grains, decreasing its nutritional value and weight of the grain (Sedlacek et al. 2001). The loss of stored grain caused by S. cerealella in certain regions accounts for over $40 \%$ (Boshra 2007). The heavy rainfall in Nagaland also provides a moist environment; moisture content increases the risk of infestation by $S$. cerealella (Butron et al. 2008) causing extensive damage to grains by larval feeding, which completes its developmental stages within the grain; the grain acts as additional protection from direct contact with insecticides (Weston, Rattlingourd 2000). Hence, S. cerealella is best controlled in the egg and larval stage immediately after hatching, before penetrating the grain.

Plant extracts can be used as a beneficial pest control substance. These extracts are natural means that have the advantage of delivering a novel mode of action, decreasing the risk of cross-resistance (Liu et al. 2014). Biological methods are safe, environment friendly and cost-effective (Mossa et al 2016). Screening of locally available plants with repellent, antifeedant and insecticidal properties as potential alternatives to synthetic or chemical insecticides are gaining importance (Shankar et al. 2013). Species of the genus Allium are known for their sulphur-containing secondary metabolites, synthesised following external 
attacks by pathogens and pests (Nwachukwu et al. 2012).

Allium chinense G.Don is a medicinal and aromatic plant cultivated in the North-Eastern part of India. The juice of this plant has moth repelling properties (Brewster 2008) and the essential oil extract of the bulb has fumigant and contact toxicity against Liposcelis bostrychophila (Liu et al. 2014). Thirty-four organo-sulphur containing compounds account for $94 \%$ of the amount of total volatiles present in essential oil from the leaf (Pino et al. 2001). In particular, allyl methyl disulphide is toxic to Tribolium castaneum adults by significantly inhibiting growth (Huang et al. 2000), and dimethyl disulphide possesses contact and fumigant toxicity against booklice (Liu et al.2014). Sulphide containing compounds like diallyl trisulphide and diallyl disulphide extracted from the essential oil of Allium sativum causes behavioural deterrence, oviposition inhibition and fumigant toxicity in S. cerealella (Yang et al. 2012). Diallyl trisulphide controls the transcriptional expression of ScerCHSA, gene, causing alteration at a histological and morphological level in S. cerealella, inhibiting the oviposition of the moth (Nwachukwu, Asawalam 2014). In addition, the plant powder from Aristolochia ringens has high insecticidal activity against $S$. cerealella (Ashamo, Akinnawonu 2012).

A literature survey showed that previous work on $A$. chinense was mostly focused on essential oil activity, while the crude extracts, which are cost-effective compared to essential oil, have been overlooked. To the best of our knowledge, there are no reports on the insecticidal activity of bulb extracts of $A$. chinense. In this context, the present study was undertaken to have a better understanding of the bio-efficacy of $A$. chinense bulb extracts as an insecticide to inhibit egg hatchability, inhibition of larvae in the developmental stages, and prevention of moth emergence.

\section{Materials and methods}

\section{Collection of plant material}

Fresh bulbs of A. chinense were collected in July 2018 from agriculture fields in Viswema village $\left(25.5615^{\circ} \mathrm{N}, 94.1450^{\circ} \mathrm{E}\right)$ Kohima district, Nagaland, India. The plant was identified by Dr. V. Rama Rao, Regional Ayurvedic Research Institute for Metabolic Disorders (Central Council for Research in Ayurvedic Sciences, Ministry of AYUSH, Govt. of India). A specimen was submitted in the Medicinal Plant Herbarium at the Botany Department, Bangalore University (voucher No. RRCBI-mus 244). The bulbs were washed with distilled water and dried in the shade until constant weight. Plant material was further ground to a fine powder by using an electric grinder and sieved using a 200-mesh sieve.

\section{Extraction}

Twenty grams of powdered A. chinense bulb was extracted separately using a Soxhlet extractor with $200 \mathrm{~mL}$ of either hexane, petroleum ether, chloroform, methanol, ethanol, or distilled water (Rhetso et al. 2020). The extract was separated from the solvent using a rotary evaporator at 30 to $40{ }^{\circ} \mathrm{C}$ for non-polar solvents and 40 to $50{ }^{\circ} \mathrm{C}$ for polar solvents. After extraction, stock solutions of $0.5,1$ and $2 \%$ concentration of the extracts were prepared using the same solvent used for extraction, for further experimental use.

\section{Insect culture and collection of eggs}

Eggs of S. cerealella were obtained from the Division of Entomology, Indian Agricultural Research Institute, New Delhi in July 2018. An incubator was used to maintain the insect culture at $25 \pm 2{ }^{\circ} \mathrm{C}$ temperature and $70 \pm 5 \%$ relative humidity. The insects were reared in $1 \mathrm{~L}$ bottles covered with muslin cloth with $250 \mathrm{~g}$ of disinfected unbroken paddy (crude rice grain). The oviposition substrate consisted of a smooth black cardboard folded at intervals and inserted into the culture bottle; the eggs of S. cerealella were collected using a brush for further experimentation (Joshi et al. 2013).

\section{Effect of bulb extract on the developmental stage and moth emergence of $\mathrm{S}$. cerealella}

Twenty grams of paddy grain were weighed and placed in a $250 \mathrm{~mL}$ bottle and further mixed with $5 \mathrm{~mL}$ of the extract at each concentration $(0.5,1$ and $2 \%)$, using a glass rod to ensure equal spread on the grain. The bottles were left in an oven at $60{ }^{\circ} \mathrm{C}$ for solvent evaporation for $12 \mathrm{~h}$. Paddy grain $(20 \mathrm{~g})$ treated with $5 \mathrm{~mL}$ of the solvent (water, ethanol, methanol, chloroform, petroleum ether, and hexane) and $20 \mathrm{~g}$ of untreated paddy grain were used as controls.

Twenty eggs ( 0 to $24 \mathrm{~h}$ old) of $S$. cerealella were introduced into each bottle. The bottles were covered with a muslin cloth, and left for 20 days for moth emergence. The day of moth emergence and the total number of moths emerged were recorded, and the percentage of mortality was calculated. From the $20^{\text {th }}$ day onwards, the bottles were checked daily for moth emergence until no moth emergence was observed for 10 consecutive days. The experiment was then ceased. Finally, the grains were weighed for each treatment and percentage weight loss was calculated with the following formula:

$$
\left[\left(\mathrm{W}_{1}-\mathrm{W}_{2}\right) \div \mathrm{W}_{1}\right] \times 100 \text {, }
$$

where $\mathrm{W}_{1}$ and $\mathrm{W}_{2}$ represent weight of paddy seed before and after the experiment, respectively. All experiments were performed in four replicates.

\section{Statistical analysis}

The data obtained in this study were analysed by oneway analysis of variance (ANOVA) at $5 \%$ probability. The significant difference between different concentrations of extracts was evaluated using Tukey's multiple comparisons test in Prism V. 5.00 (Graphpad Inc. USA). Probit analysis was used for calculating the $\mathrm{LC}_{50}, 95 \%$ lower and upper confidence limits (LCL - UCL) (Finney 1971). Corrected mortality was calculated using the Abbott (1925) method. 
Table 1. Time of moth emergence, moth mortality and weight loss of paddy seed infested with Sitotroga cerealella and treated with ethanol extract of Allium chinense bulbs. Data are means \pm SE. Means with identical letters within the column are not statistically significantly different. LCL, lower confidence limit; UCL, upper confidence limit

\begin{tabular}{|c|c|c|c|c|}
\hline $\begin{array}{l}\text { Treatment, } \\
\text { concentration (\%) }\end{array}$ & $\begin{array}{c}\text { Time of moth } \\
\text { emergence (days) }\end{array}$ & Mortality (\%) & $\begin{array}{c}\text { Efficacy (corrected } \\
\text { mortality) }\end{array}$ & Weight loss (\%) \\
\hline Control & $28.75 \pm 0.47 a$ & $18.75 \pm 0.47 a$ & & $36.65 \pm 0.13 \mathrm{a}$ \\
\hline Ethanol control & $29.75 \pm 1.03 \mathrm{a}$ & $20.00 \pm 0.40 \mathrm{a}$ & 1.54 & $36.32 \pm 0.13 \mathrm{a}$ \\
\hline 0.5 & $33.50 \pm 0.64 b$ & $62.50 \pm 0.64 b$ & 53.85 & $17.42 \pm 0.56 b$ \\
\hline 1.0 & $33.75 \pm 0.47 b$ & $81.25 \pm 0.47 c$ & 76.92 & $6.24 \pm 0.41 c$ \\
\hline 2.0 & $0.00 \pm 0.00 c$ & $100.00 \pm 0.00 \mathrm{~d}$ & 100.00 & $2.55 \pm 0.39 \mathrm{~d}$ \\
\hline$F$ & 522.80 & 254.30 & & 1910.00 \\
\hline$P$ & $<0.0001$ & $<0.0001$ & & $<0.0001$ \\
\hline $\mathrm{LC}_{50}(\mathrm{LCL}-\mathrm{UCL})$ & & $0.45(0.21-0.68)$ & & \\
\hline
\end{tabular}

\section{Results}

\section{Effect of bulb extracts on the moth emergence of}

\section{S. cerealella}

The efficacy of the six extracts with different solvents in inhibiting the developmental stages of $S$. cerealella was evaluated by recording the emergence from egg to adult stage in terms of number of days. The larval stage and pupal stages occurred within the grains. Effects of treatment with solvent alone and control were similar without any significant difference (Tables 1 to 6 ). The greatest effect was obtained using $2 \%$ ethanol and $2 \%$ petroleum ether extracts. These treatments showed $100 \%$ moth control and no moth emergence (Tables 1 and 2). Chloroform extract at 2\% concentration was found to be effective in prolonging the developmental stage of moth emergence (day $42.50 \pm 0.28$ ), in comparison with emergence in the control (day $28.75 \pm$ 0.47 ) (Table 3). The methanol and hexane extracts showed inhibition, but did not cause complete mortality (Tables 4 and 5). There was no significant difference between effects of the aqueous extract on moth emergence, compared to the control (Table 6).

\section{Effect of bulb extracts on the mortality of S. cerealella}

The analysis of mean mortality using one-way ANOVA showed that effect of all treatments significantly differed from control and solvent alone. Mortality increased with higher extract concentration. Among the extracts, petroleum ether showed the highest potency to kill 50\% of S. cerealella, with $\mathrm{LC}_{50}$ value of $0.395 \%(0.16$ to $0.62 \%)$, followed by ethanol extract with $\mathrm{LC}_{50} 0.45 \%$ ( 0.21 to $0.68 \%$ ) (Tables 1 and 2). In treatments with ethanol and petroleum ether extracts, complete moth control was observed at $2 \%$ concentration. In chloroform and hexane extract (Table 3 and 5), 2\% concentration was effective in decreasing number of moths. In methanol and aqueous extract, $1 \%$ concentration was equally effective as $2 \%$ concentration on moth mortality (Table 4 and 6). However, the lowest mortality was observed in the extract treatment.

\section{Effect of bulb extracts on the weight loss of infested paddy}

There was no significant difference in weight loss of infested paddy between control and solvent treatments. The maximum mean weight loss of paddy was recorded for the aqueous treatment, as the mortality of $S$. cerealella was very poor (Table 6); ethanol extract treatment showed highest effect, with minimal weight loss of paddy seed (Table 1). Weight loss was best controlled in $2 \%$ ethanol extract, with $2.55 \pm 0.39 \%$ loss, while maximum loss was observed in the control, with $36.65 \pm 0.13 \%$ due to high infestation.

Table 2. Time of moth emergence, moth mortality and weight loss of paddy seed infested with Sitotroga cerealella and treated with petroleum ether extract of Allium chinense bulbs. Data are means \pm SE. Means with identical letters within the column are not statistically significantly different. LCL, lower confidence limit; UCL, upper confidence limit

\begin{tabular}{|c|c|c|c|c|}
\hline $\begin{array}{l}\text { Treatment, } \\
\text { concentration (\%) }\end{array}$ & $\begin{array}{c}\text { Time of moth } \\
\text { emergence (days) }\end{array}$ & Mortality (\%) & $\begin{array}{c}\text { Efficacy (corrected } \\
\text { mortality) }\end{array}$ & Weight loss (\%) \\
\hline Control & $28.75 \pm 0.47 \mathrm{a}$ & $18.75 \pm 0.47 \mathrm{a}$ & & $36.65 \pm 0.13 \mathrm{a}$ \\
\hline Petroleum ether control & $29.75 \pm 0.47 \mathrm{a}$ & $20.00 \pm 0.37 \mathrm{a}$ & 1.54 & $36.11 \pm 0.93 \mathrm{a}$ \\
\hline 0.5 & $40.00 \pm 0.40 \mathrm{~b}$ & $65.00 \pm 0.40 b$ & 56.92 & $11.10 \pm 0.35 \mathrm{~b}$ \\
\hline 1.0 & $41.25 \pm 0.47 \mathrm{~b}$ & $80.00 \pm 0.40 c$ & 75.38 & $5.50 \pm 0.25 c$ \\
\hline 2.0 & $0.00 \pm 0.00 c$ & $100.00 \pm 0.00 \mathrm{~d}$ & 100.00 & $4.02 \pm 0.25 c$ \\
\hline$F$ & 1620.00 & 361.60 & & 1235.00 \\
\hline$P$ & $<0.0001$ & $<0.0001$ & & $<0.0001$ \\
\hline $\mathrm{LC}_{50}(\mathrm{LCL}-\mathrm{UCL})$ & & $0.39(0.16-0.62)$ & & \\
\hline
\end{tabular}


Table 3. Time of moth emergence, moth mortality and weight loss of paddy seed infested with Sitotroga cerealella and treated with chloroform extract of Allium chinense bulbs. Data are means \pm SE. Means with identical letters within the column are not statistically significantly different. LCL, lower confidence limit; UCL, upper confidence limit

\begin{tabular}{lcccc}
$\begin{array}{l}\text { Treatment, } \\
\text { concentration (\%) }\end{array}$ & $\begin{array}{c}\text { Time of moth } \\
\text { emergence (days) }\end{array}$ & Mortality (\%) & $\begin{array}{c}\text { Efficacy (corrected } \\
\text { mortality) }\end{array}$ & Weight loss (\%) \\
Control & $28.75 \pm 0.47 \mathrm{a}$ & $18.75 \pm 0.47 \mathrm{a}$ & & $36.65 \pm 0.13 \mathrm{a}$ \\
\hline Chloroform control & $29.50 \pm 0.64 \mathrm{a}$ & $25.00 \pm 0.40 \mathrm{a}$ & 44.62 & $36.36 \pm 0.42 \mathrm{a}$ \\
\hline 0.5 & $40.00 \pm 0.40 \mathrm{~b}$ & $55.00 \pm 0.40 \mathrm{~b}$ & 64.62 & $21.16 \pm 0.10 \mathrm{~b}$ \\
1.0 & $40.25 \pm 0.75 \mathrm{bc}$ & $71.25 \pm 0.47 \mathrm{c}$ & 84.62 & $7.10 \pm 0.85 \mathrm{~d}$ \\
\hline 2.0 & $42.50 \pm 0.28 \mathrm{c}$ & $87.50 \pm 0.28 \mathrm{~d}$ & & 710.80 \\
\hline$F$ & 146.50 & 198.50 & & $<0.0001$ \\
\hline$P$ & $<0.0001$ & $<0.0001$ & & $\mathrm{c}$ \\
\hline $\mathrm{LC}_{50}(\mathrm{LCL}-\mathrm{UCL})$ & & $0.60(0.28-0.92)$ & &
\end{tabular}

Table 4. Time of moth emergence, moth mortality and weight loss of paddy seed infested with Sitotroga cerealella and treated with methanol extract of Allium chinense bulbs. Data are means \pm SE. Means with identical letters within the column are not statistically significantly different. LCL, lower confidence limit; UCL, upper confidence limit

\begin{tabular}{lcccc}
$\begin{array}{l}\text { Treatment, } \\
\text { concentration (\%) }\end{array}$ & $\begin{array}{c}\text { Time of moth } \\
\text { emergence (days) }\end{array}$ & Mortality (\%) & $\begin{array}{c}\text { Efficacy (corrected } \\
\text { mortality) }\end{array}$ & Weight loss (\%) \\
Control & $28.75 \pm 0.47 \mathrm{a}$ & $18.75 \pm 0.47 \mathrm{a}$ & 6.15 & $36.65 \pm 0.13 \mathrm{a}$ \\
\hline Methanol control & $29.00 \pm 0.40 \mathrm{ab}$ & $23.75 \pm 0.25 \mathrm{a}$ & 36.92 & $36.45 \pm 0.07 \mathrm{a}$ \\
\hline 0.5 & $29.75 \pm 0.75 \mathrm{ab}$ & $48.75 \pm 0.62 \mathrm{~b}$ & 50.77 & $28.58 \pm 0.90 \mathrm{~b}$ \\
\hline 1.0 & $31.25 \pm 0.62 \mathrm{~b}$ & $60.00 \pm 0.40 \mathrm{c}$ & 61.54 & $14.88 \pm 0.46 \mathrm{~d}$ \\
\hline 2.0 & $33.75 \pm 0.47 \mathrm{c}$ & $68.75 \pm 0.47 \mathrm{c}$ & & 305.00 \\
$F$ & 13.42 & 89.48 & & $<0.0001$ \\
$P$ & $<0.0001$ & $<0.0001$ & & $\mathrm{c}$ \\
\hline $\mathrm{LC}_{50}(\mathrm{LCL}-\mathrm{UCL})$ & & $0.62(0.16-1.08)$ & &
\end{tabular}

\section{Comparison of the effect of $2 \%$ concentration extract on}

\section{S. cerealella}

The days taken for moth emergence at $2 \%$ concentration of the six extracts were compared (Fig. 1). Ethanol extract was as effective as petroleum ether extract in controlling $S$. cerealella, with zero moth emergence. Hence, the highest mortality, with complete control, was observed in ethanol and petroleum ether extracts.

\section{Discussion}

Plant extracts have been shown to reduce and prevent hatching of eggs and development into larva and adult stages, which are the most damaging stages of insects (Soujanya et al.2016). If egg hatching can be controlled, then the other destructive stages can be eliminated. According to our findings, petroleum ether and ethanol extract showed higher ovicidal activity compared to methanol, hexane

Table 5. Time of moth emergence, moth mortality and weight loss of paddy seed infested with Sitotroga cerealella and treated with hexane extract of Allium chinense bulbs. Data are means \pm SE. Means with identical letters within the column are not statistically significantly different. LCL, lower confidence limit; UCL, upper confidence limit

\begin{tabular}{|c|c|c|c|c|}
\hline $\begin{array}{l}\text { Treatment, } \\
\text { concentration (\%) }\end{array}$ & $\begin{array}{c}\text { Time of moth } \\
\text { emergence (days) }\end{array}$ & Mortality (\%) & $\begin{array}{c}\text { Efficacy (corrected } \\
\text { mortality) }\end{array}$ & Weight loss (\%) \\
\hline Control & $28.75 \pm 0.47 a$ & $18.75 \pm 0.47 a$ & & $36.65 \pm 0.13 a$ \\
\hline Hexane control & $29.00 \pm 0.40 \mathrm{a}$ & $21.25 \pm 0.47 \mathrm{a}$ & 3.08 & $36.31 \pm 0.25 \mathrm{a}$ \\
\hline 0.5 & $35.75 \pm 0.47 b$ & $48.75 \pm 0.25 b$ & 36.92 & $27.15 \pm 0.51 b$ \\
\hline 1.0 & $37.5 \pm 0.28 b c$ & $56.25 \pm 0.75 b$ & 46.15 & $14.99 \pm 0.43 c$ \\
\hline 2.0 & $39.5 \pm 0.64 c$ & $75.00 \pm 0.40 c$ & 69.23 & $10.41 \pm 0.25 \mathrm{~d}$ \\
\hline$F$ & 109.00 & 91.55 & & 1218.00 \\
\hline$P$ & $<0.0001$ & $<0.0001$ & & $<0.0001$ \\
\hline $\mathrm{LC}_{50}(\mathrm{LCL}-\mathrm{UCL})$ & & $0.82(0.46-1.19)$ & & \\
\hline
\end{tabular}


Table 6. Time of moth emergence, moth mortality and weight loss of paddy seed infested with Sitotroga cerealella and treated with water extract of Allium chinense bulbs. Data are means \pm SE. Means with identical letters within the column are not statistically significantly different. LCL, lower confidence limit; UCL, upper confidence limit

\begin{tabular}{lcccc}
$\begin{array}{l}\text { Treatment, } \\
\text { concentration (\%) }\end{array}$ & $\begin{array}{c}\text { Time of moth } \\
\text { emergence (days) }\end{array}$ & Mortality (\%) & $\begin{array}{c}\text { Efficacy (corrected } \\
\text { mortality) }\end{array}$ & Weight loss (\%) \\
Control & $28.75 \pm 0.47 \mathrm{a}$ & $18.75 \pm 0.47 \mathrm{a}$ & -3.08 & $36.65 \pm 0.13 \mathrm{a}$ \\
\hline Water control & $30.00 \pm 0.40 \mathrm{ab}$ & $16.25 \pm 0.25 \mathrm{a}$ & 38.46 & $37.03 \pm 0.42 \mathrm{a}$ \\
\hline 0.5 & $31.50 \pm 0.64 \mathrm{cb}$ & $50.00 \pm 0.40 \mathrm{~b}$ & 44.62 & $29.85 \pm 0.82 \mathrm{~b}$ \\
1.0 & $32.00 \pm 0.47 \mathrm{c}$ & $55.00 \pm 0.40 \mathrm{bc}$ & 50.77 & $30.45 \pm 0.47 \mathrm{~b}$ \\
\hline 2.0 & $33.00 \pm 0.28 \mathrm{c}$ & $60.00 \pm 0.40 \mathrm{c}$ & & $23.78 \pm 1.46 \mathrm{c}$ \\
\hline$F$ & 14.43 & 109.90 & & 46.61 \\
\hline$P$ & $<0.0001$ & $<0.0001$ & & $<0.0001$ \\
\hline $\mathrm{LC}_{50}(\mathrm{LCL}-\mathrm{UCL})$ & & $1.83(1.27-2.39)$ & &
\end{tabular}

and aqueous extract. The higher activity of ethanol and petroleum ether extracts against moth emergence may be due to the polarity of the solvent used for extraction, as polarity plays a significant role in completely extracting all of the active components. The insecticidal potential of ethanol and petroleum ether extract in controlling stored grain pests was shown by $100 \%$ control of S. cerealella emergence at $2 \%$ concentration. Extracts of $A$. chinense are known for their organo-sulphur (Pino et al. 2001; Liu et al. 2014) and saponin content (Wang et al. 2016; Yao et al. 2016). The juice of $A$. chinense also contains mothrepelling properties (Brewster 2008). Saponins have an insecticidal property, which can inhibit egg hatching, cause moth mortality and interfere with feeding behaviour and growth regulation (Chaieb 2010). The lower larval or pupal survival rate in grains treated with ethanol and petroleum ether extract may be due to a broad spectrum of effects on different developmental stages of S. cerealella. The deterrent effect of $A$. chinense extracts was probably due to the presence of saponin compounds, which caused antifeeding activity (Faizal, Geelen 2013).

In the present study, the highest inhibition on the developmental period was observed in chloroform extract

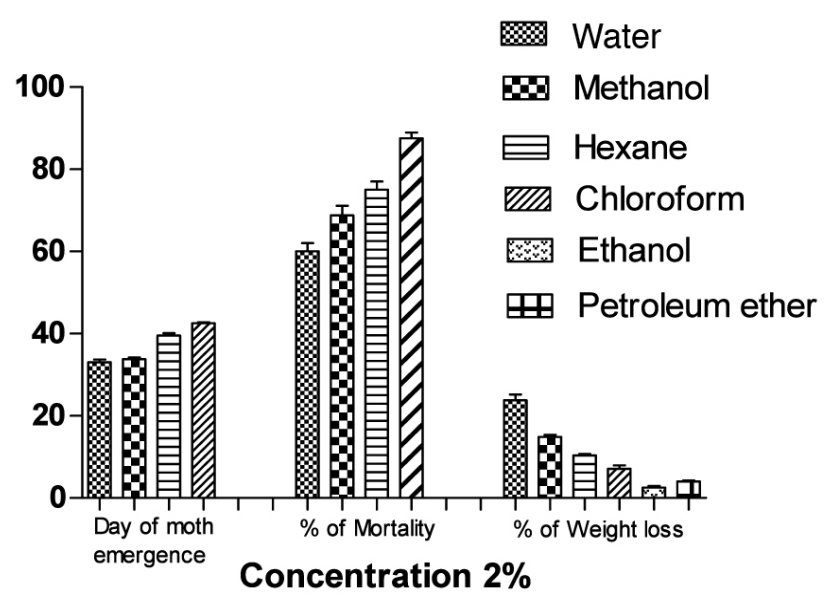

Fig. 1. Insecticidal activity of the six extracts of Allium chinense bulb at $2 \%$ concentration.
- moth emergence occurred on day 42.50 when $2 \%$ concentration was used, while at $1 \%$ concentration, moth emergence was observed on day 40.25 , and on day 40 in $0.5 \%$, whereas in the control emergence was observed on day 28.75. Saponins can regulate the growth of numerous insect species by increasing the time period of larval stages and also delay the time needed to reach maximum size (Adel et al. 2000). The $2 \%$ chloroform extract was effective in causing mortality (87.50\%) and reducing weight loss. Significant mortality was also observed in $2 \%$ hexane (75.00\%), methanol (68.75\%) and water $(60.00 \%)$ extracts, with significant reduction of moth emergence, lower larval survival capacity. This shows the efficacy of $A$. chinense extract as a potential insecticide. With application of higher dosage, moth emergence can be completely controlled, as shown earlier (Soujanya et al. 2016). All extracts showed a significant reduction of moth emergence, compared to the control; the time taken for moth emergence increased as concentration increased. A similar result was reported in experiments on Callosobruchus chinensis where saponin reduced the rate of adult emergence (Weissenberg et al. 1998).

The percentage weight loss of paddy was controlled best by ethanol extract $(2.55 \%)$ and petroleum ether extract $(4.02 \%)$ treatment; this loss in paddy weight may have been due to infestation of the grain by larvae, which would have penetrated the grain but died in the developmental stages due to the growth-inhibiting activity of the extracts. Similar results were observed in sweet flag, turmeric and neem extract (Iqbal et al. 2010). The number of insects emerging is a principal factor determining the efficacy of the extract, as it directly affects weight loss of the grain in storage.

The potential of $A$. chinense bulb extracts as an insecticide for control of stored grains pests was shown, as $S$. cerealella adult emergence was fully controlled by using $2 \%$ ethanol and $2 \%$ petroleum ether bulb extract. The study showed the insecticidal potential of the six extracts of $A$. chinense bulb against $S$. cerealella. Similar observations were made by Ashamo and Akinnawonu (2012) in experiments 
using stem bark ethanol extract of Aristolochia ringens, Khaya ivorensis, Strophanthus hispidus, and root extract of Zanthoxylum zanthoxyloide, where $100 \%$ moth mortality was recorded. The flower extract of Tithonia diversifolia and Dimorphandra mollis has ovicidal effect on S. cerealella; T. diversifolia was also reported to have larvicidal activity and reduced the egg hatching (Fouad et al. 2014). Stem bark powder of Alstonia boonei and leaf powder of Acalypha godseffienna showed control of S. cerealella moth, but could not elicit 100\% mortality (Oyeniyi 2018). The root bark powder of Cleistopholis patens also showed high mortality of S. cerealella moth (Akinneye, Oyeniyi. 2016).

However, the effectiveness of the six extracts against $S$. cerealella differed depending on concentration used. Extracts and essential oil from garlic (Allium sativum) have been reported and products have been marketed for pest control (Kimparis et al. 2009). Still, there is no previous report on the insecticidal activity of solvent extracts of $A$. chinense bulbs.

\section{Conclusions}

The present study concludes that ethanol and petroleum ether bulb extracts of $A$. chinense have promising active bioconstituents for controlling the emergence of S. cerealella adults from eggs. The bulb extract can be used as a potential bioinsecticide for pest control in post-harvest protection, considering its easy availability, and mass production of the extract is possible. Further, the plant is edible, has therapeutic value and it is non-toxic. For the first time, this work was carried out using the crude extract of $A$. chinense bulb to control storage pest $S$. cerealella. Further evaluation leading to separation, screening of bioactive compounds and enhancing their activity is recommended.

\section{Acknowledgements}

The authors acknowledge the University Grant Commission (UGC) Maulana Azad National Fellowship (MANF), for providing Senior Research Fellowship to the first author. Authors are also grateful to the Department of Botany, Bangalore University, Bangalore - 560056 for laboratory facility and Division of Entomology Indian Agriculture Research Institute, New Delhi for providing the Sitotroga cerealella culture.

\section{References}

Abbott W.S. 1925. A method of computing the effectiveness of an insecticide. J. Econ. Entomol. 18: 265-267.

Adel M.M., Sehnal F., Jurzysta M. 2000. Effects of alfalfa saponins on the moth Spodoptera littoralis. J. Chem. Ecol. 26: 1065-1078.

Akinneye J.O., Oyeniyi E. 2016. Insecticidal efficacy of Cleistopholis patens (Benth) against Sitotroga cerealella Olivier (Lepidoptera: Gelechiidae) infesting rice grains in Nigeria. J. Crop Protect. 5: 1-10.

Ashamo M.O., Akinnawonu O. 2012. Insecticidal efficacy of some plant powders and extracts against the Angoumois grain moth, Sitotroga cerealella (Olivier) (Lrpidoptera: Gelechiidae).
Arch. Phytopathol. Plant Protect. 45: 1051-1058.

Boshra S.A. 2007. Effect of high-temperature pre-irradiation on reproduction and mating competitiveness of male Sitotroga cerealella (Olivier) and their F-1 progeny. J. Stored Prod. Res. 43: 73-78.

Brewster J.L. 2008. Onions and Other Vegetable Alliums. $2^{\text {nd }}$ Ed. CABI, Oxfordshire.

Bushra S., Aslam, M., Aziz M.A., Ahmed M. 2013. Grain damage, viability and weight loss in different barley cultivars due to Sitotroga cerealella (Oliv.) infestation. Arch. Phytopathol. Plant Protect. 46: 205-214.

Butrón A., Romay M.C., Ordás, A., Malvar R.A., Revilla P. 2008. Genetic and environmental factors reducing the incidence of the storage pest Sitotroga cerealella in maize. Entomol. Exp. Appl. 128: 421-428.

Chaieb I. 2010. Saponins as insecticides: A review. Tunis. J. Plant Protect. 5: 39-50.

Faizal A and Geelen D. 2013. Saponins and their role in biological processes in plants. Phytochem. Rev. 12: 877-893.

Finney D.J. 1971. Probit Analysis. $3^{\text {rd }}$ Ed. Cambridge University Press, Cambridge.

Fouad H.A., Faroni L.R.D., Tavares W.S., Ribeiro R.C., Freitas S.S., Zanuncio J.C. 2014. Botanical extracts of plants from the Brazilian Cerrado for the integrated management of Sitotroga cerealella (Lepidoptera: Gelechiidae) in stored grain. J. Stored Prod. Res. 57: 6 -11.

Huang Y., Chen S.X., Ho S.H. 2000. Bioactivities of methyl allyl disulfide and diallyl trisulfide from essential oil of garlic to two species of stored-product pests, Sitophilus zeamais (Coleoptera: Curculionidae) and Tribolium castaneum (Coleoptera: Tenebrionidae). J. Econ. Entomol. 93: 537-543.

Iqbal J., Jilani G., Aslam M.Z. 2010. Growth inhibiting effects of plant extracts against the grain moth, Sitotroga cerealella (Oliv.) (Gelechiidae: Lepidoptera). Pak. J. Zool. 42: 597-601.

Jamir I.T.A., Ao M.A., Khound J.N. 2013. Management practices against angoumois grain moth, Sitotroga cerealella (Olivier) in stored paddy in Nagaland, India. Int. J. Bioresour. Stress Manage. 4: 58-63.

Joshi S., Ballal., C.R., Lakshmi B.L. 2013. Small scale production technique for Angoumois grain moth, Sitotroga cerealella (Olivier). In: $13^{\text {th }}$ Workshop of the IOBC Global Working Group on Mass Rearing and Quality Assurance, 6-8 November 2013. Proceedings. Movenpick Hotel \& Spa, Bangalore, India. Pp. 22-23.

Kimparis A., Kioulos E., Koliopulos G., Polissiou M.G., Michaelakis A. 2009. Coactivity of sulfide ingredients: A new perspective of the larvicidal activity of garlic essential oil against mosquitoes. Pest Manage. Sci. 65: 249-254.

Liu X.C., Lu X.N., Liu Q.Z., Liu Z.L. 2014. Evaluation of insecticidal activity of the essential oil of Allium chinense G. Don and its major constituents against Liposcelis bostrychophila Badonnel. J. Asia-Pac. Entomol. 17: 853-856.

Mossa A.T.H. 2016. Green pesticides: Essential oils as biopesticides in insect-pest management. J. Environ. Sci. Technol. 9: 354-378.

Nwachukwu I.D., Asawalam E.F. 2014. Evaluation of freshly prepared juice from garlic (Allium sativum L.) as a biopesticide against the maize weevil, Sitophilus zeamais (Motsch.) (Coleoptera: Curculionidae). J. Plant Protect. Res. 54: 132-138.

Oyeniyi E.A. 2018. Assessment of powders of Alstonia boonei (De wild) and Acalypha godseffienna (Muel Arg.) as protectant of rice grains against infestation by Sitotroga cerealella (Olivier, 1789) (Lepidoptera: Gelechiidae). Braz. J. Biol. Sci. 5: 489-497. 
Pino J.A., Fuentes, V., Correa M.T. 2001. Volatile constituents of Chinese chive (Allium tuberosum Rottl. ex Sprengel) and rakkyo (Allium chinense G. Don). J. Agric. Food Chem. 49: 1328-1330.

Rhetso T., Shubharan, R., Roopa M.S. Sivaram V. 2020. Chemical constituents, antioxidant, and antimicrobial activity of Allium chinense G. Don. Future J. Pharmac. Sci. 6: 102.

Sedlacek J.D., Komaravalli S.R., Hanley A.M., Price B.D., Davis P.M. 2001. Life history attributes of indian meal moth (Lepidoptera: Pyralidae) and angoumois grain moth (Lepidoptera: Gelechiidae) reared on transgenic corn kernels. J. Econ. Entomol. 94: 586-592.

Shankar B.S., Saravanan T., Ragavi M., Kaviya G., Anushree A., Samraj D.A., Tennyson S. 2013. Screening of local plants for their repellent activity against mosquitoes (Diptera: Culicidae). J. Mosquito Res. 3: 97-104.

Soujanya P.L., Sekhar J.C., Kumar P., Sunil N., Prasad C.V., Mallavadhani U.V. 2016. Potentiality of botanical agents for the management of post harvest insects of maize: a review. J. Food Sci. Technol. 53: 2169-2184.

Valdes A., Siamwalla A. 1981. Food Insecurity in Developing
Countries. Westview Press, Boulder.

Wang Y., Li C., Xiang L., Huang W., He X.2016.Spirostanol saponins from Chinese onion (Allium chinense) exert pronounced antiinflammatory and anti-proliferative activities. J. Funct. Foods 25: 208-219.

Weissenberg M., Levy A., Svoboda J.A., Ishaaya I. 1998. The effect of some Solanum steroidal alkaloids and glycoalkaloids on larvae of the red flour beetle, Tribolium castaneum, and the tobacco hornworm, Manduca sexta. Phytochemistry 47: 203209.

Weston P and Rattlingourd P.L. 2000. Progeny production by Tribolium castaneum (Coleoptera: Tenebrionidae) and Oryzaephilus surinamensis (Coleoptera: Silvanidae) on maize previously infested by Sitotroga cerealella (Lepidoptera: Gelechiidae). J. Econ. Entomol. 93: 533-536.

Yang F.L., Zhu F., Lei C.L. 2012. Insecticidal activities of garlic substances against adults of grain moth, Sitotroga cerealella (Lepidoptera: Gelechiidae). Insect Sci. 19: 205-212.

Yao Z.H., Qin Z.F., Dai Y., Yao X.S. 2016. Phytochemistry and pharmacology of Alii macrostemonis Bulbus, a traditional Chinese medicine. Chin. J. Nat. Med. 14: 481-498. 